\title{
JUURNAL.RU
}

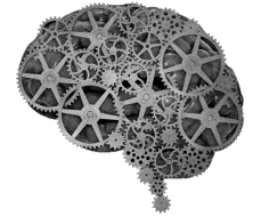

COMPANY GROUP "INTELLEKT"

Тюльнина В.П. Национальный исследовательский технологический университет стали и сплавов Москва, Россия

doi: 10.18411/lj2016-3-80

\section{К вопросу о синтаксической синонимии и смысле высказывания}

Наличие в языке различных способов прапроцедурного изменения исходной структуры высказывания, в результате которого образуются различные грамматические конструкции, способные передавать по своему смысловому содержанию будто бы один и тот же факт реального мира, побудило многих лингвистов рассматривать эти грамматические конструкции как синонимичные формы выражения одного и того же содержания, то есть как синтаксические синонимы. В лингвистической литературе синонимическими признаются только те лексические единицы, которые обозначают один и тот же предмет или явление действительности. Говоря об общем значении, лингвисты зачастую смешивают его с объектом реального мира, в результате чего признание синонимичности языковых выражений по признаку тождества предмета выводит ее из языковой сферы, так как сравнение двух или более предметов не есть еще сравнение самих языковых выражений по семантике. Если исходить при определении синонимии из предметной общности, то все выражения, в которых присутствуют признаки тех или иных предметов или явлений, будут синонимами. Тогда резонно возникает вопрос о том, что является определяющим фактором для установления синтаксических синонимов и какова роль некоего «общего» смысла двух сравниваемых структур при установлении их синонимичности. 
Многие исследователи называют в качестве определяющего критерия при выявлении синтаксических синонимов взаимозаменяемость грамматических конструкций в процессе коммуникации. Если строго придерживаться этого принципа, то к классу синтаксических синонимов будут относиться такие выражения, которые вообще не могут рассматриваться как синонимичные с точки зрения языкового содержания. Ведь взаимозаменяемость есть в сущности не что иное как обыкновенная субституция, используемая часто при исследовании лексической синонимии, и именно по принципу взаимозаменяемости создаются всевозможные перифразы, которые являются отнюдь не тождественными по своему смысловому наполнению. Мы вправе, к примеру, рассматривать с позиций взаимозаменяемости высказывания типа « Он обидел друга - Друг обиделся на него», но подобная взаимозаменяемость не позволяет квалифицировать эти высказывания как синтаксические синонимы, поскольку смысловое наполнение этих грамматических структур совершенно различно. Заменить друг друга они в принципе могут лишь в том случае, если мы отвлечемся от языкового содержания и будем рассматривать их только по отношению к некоему «единому факту». При таком рассмотрении лингвистический анализ семантической структуры высказывания переносится в предметную сферу и как бы подменяется экстралингвистической соотнесенностью данного высказывания с ситуацией объективной действительности. Кажущаяся на первый взгляд способность некоторых грамматических конструкций подвергаться взаимозаменяемости в процессе коммуникации не должна вводить исследователя в заблуждение относительно их синонимичности, поскольку для ее установления требуется логикосемантический анализ содержательной стороны высказываний. В противном случае опора только на взаимозаменяемость приводит к отождествлению конкретного смыслового наполнения высказывания с некоторым «общим смыслом», соотнесенным с каким-то «единым фактом» действительности. 
В качестве синонимичных называют порой конструкции, в которых предмет высказывания выражен именем в именительном или творительном падеже (ср. предложения «Он был врачом» и «Он был врач») . Однако, нам представляется, что речь здесь идет не о синтаксической синонимии, а о двух различных высказываниях с разным смысловым наполнением, так как именительный и творительный предикативный при внимательном их анализе различаются в семантическом отношении: творительный падеж в функции предикатива указывает на временный (не стабильно присутствующий) признак, a именительный предикативный чаще всего передает постоянный признак предмета. Предложение «Он был врачом» говорит о том, что в настоящее время субъект уже не выполняет этот вид деятельности, в то время как предложение «Он был врач» содержит постоянный признак субъекта, в частности, называется его профессия. Значит, мы имеем дело с различным смысловым содержанием высказываний. Следует, однако, уточнить, что когда речь идет об абсолютной синонимии, то имеются в виду такие единицы языка, сигнификаты которых полностью совпадают, независимо от их контекстного употребления. Так, к примеру, если сигнификаты лексем «языкознание» - «языковедение» совпадают полностью вне дистрибуции их употребления, то и высказывания « Студентам предстоит сдать экзамен по языкознанию» - «Студентам предстоит сдать экзамен по языковедению» можно считать абсолютными синтаксическими синонимами, выражающими идентичное смысловое содержание. Другими словами, если предложения тождественны по их денотату, то они тождественны и по их сигнификату.

Следуя этой точке зрения, можно предположить, что в языке присутствует ограниченное количество синонимических способов выражения идентичного содержания, поскольку обилие таких случаев привело бы в процессе коммуникации к тавтологии, которая мешала бы процессу коммуникации. Иллюзия богатой синонимии в языке создается только благодаря весьма приблизительной и упрощенной оценке значений слов, не выдерживающей 
никакой критики при строгом их определении. Пожалуй, именно это имел в виду Г.О. Винокур, когда писал: «...так называемая синонимичность средств языка, если иметь дело не с лингвистической абстракцией, а с живым и реальным языком, с тем языком, который фактически существует в истории, является просто-напросто фикцией. Синоним является синонимом только до тех пор, пока он находится в словаре [1].

Кроме абсолютной синонимии существует и так называемая синонимия функциональная. Если абсолютная синонимия предполагает абсолютное тождество сигнификатов языковых единиц вне их контекстного употребления, то сигнификаты функциональных синонимов являются абсолютно тождественными только в контексте их употребления. Так, например, сигнификативные значения лексических единиц «правильный» и «верный», «умножить» и «помножить» не совпадают вне их контекстного употребления, то есть они не являются абсолютными синонимами, хотя это близкие по значению слова. Но данные языковые единицы могут быть квалифицированы как функциональные синонимы, если в контексте высказываний «Расчет командира был верный» и «Расчет командира был правильный», «Два умноженное на два равно четыре» и «Два помноженное на два равно четыре» их сигнификативные значения окажутся абсолютно тождественными, контекстно тождественными, так их значения полностью совпадают только в данном контексте.

Особую проблему представляет вопрос о стилистических синонимах как единицах с различной эмоционально-стилистической окраской, которые якобы указывают на один и тот же предмет или явление действительности ( ср. «лобчело», «очи - глаза») ) и могут считаться абсолютными синонимами. Однако, думается, что любое слово, образующее стилистическую парадигму, употребляется в высказывании не для того, чтобы только указать на объект реального мира, а прежде всего охарактеризовать этот объект с определенной стороны по каким-либо его признакам или свойствам. Эту задачу такое слово выполняет с помощью экспрессивно-стилистических нюансов, содержащих 
такую информацию, которая является органической частью смыслового содержания данного конкретного высказывания. Поэтому так называемые стилистические коннотации сдвигают смысл высказывания, и их анализ должен быть всегда направлен на раскрытие этих разных смыслов.

В заключение хотелось бы сказать, что предметы и явления материального мира обладают не одним, а бесчисленным множеством свойств и признаков, поэтому в вопросе синонимии синтаксических конструкций решающим фактором для установления синонимичности высказываний должно быть не предметное, а предметно-денотативное и смысловое тождество. При игнорировании этого принципа границы синтаксической синонимии определить скорее всего невозможно.

\section{Литература}

1. .О.Винокур. Проблема культуры речи. В кн.: «Русский язык в советской школе».1929,№5, с.35. 